\title{
Leaf-tissue Nutrient Dynamics in Mature Muscadine Cultivars Carlos and Noble in Georgia and North Carolina
}

\author{
Tekan S. Rana ${ }^{1}$, Erick D. Smith ${ }^{2}$, Cain Hickey ${ }^{3}$, \\ and Mark Hoffmann ${ }^{1}$
}

\begin{abstract}
AdDITIONAL INDEX WORDs. tissue sampling, Vitis rotundifolia, vine nutrition
SumMARY. More than 3000 acres of commercial muscadine (Vitis rotundifolia) vineyards exist in the southeastern United States. The muscadine wine industry is generating an economic impact of $\$ 1$ billion in North Carolina alone. Muscadines have been cultivated since the 1800 s, but muscadine vineyard fertilizer programs, tissue sampling, and nutrient sufficiency ranges continue to be based on anecdotal knowledge. While seasonal changes in tissue nutrient concentration are well documented in bunch grape (Vitis vinifera), questions remain about the seasonal and cultivar-dependent dynamics of muscadine leaf tissue nutrient concentrations. The aim of this study was to assess temporal and cultivar-related differences in tissue nutrient concentration of mature commercially grown muscadines. Leaf tissue nutrient concentration of the muscadine cultivars Carlos and Noble were assessed in three vineyards (Piedmont North Carolina, north Georgia, and south Georgia) at bloom, véraison, and postharvest in 2018 and 2019. Our results show that nitrogen $(\mathrm{N})$, phosphorus $(\mathrm{P})$, and manganese $(\mathrm{Mn})$ were generally above the recommended sufficiency ranges, with calcium increasing over the season-and $\mathrm{N}, \mathrm{P}$, and potassium decreasing over the season. 'Carlos' had significantly higher levels of $\mathrm{N}$ and $\mathrm{P}$, compared with 'Noble', while 'Noble' showed higher Mn concentration than 'Carlos'. With this evaluation, we demonstrate the need for a modification in muscadine tissue nutrient sufficiency ranges that are based on cultivar and vine growth stage.
\end{abstract}

$\mathrm{T}$ he muscadine (Vitis rotundifolia) is a native grape to the southeastern United States and has been selectively bred for

Received for publication 23 Nov. 2020. Accepted for publication 5 Mar. 2021.

Published online 26 April 2021.

${ }^{1}$ Department of Horticultural Science, North Carolina State University, 2721 Founders Drive, Raleigh, NC 27695

${ }^{2}$ Department of Horticulture, University of Georgia-Tifton Campus, 2360 Rainwater Rd, Tifton, GA 31793

${ }^{3}$ Penn State Extension Horticulture: Viticulture and Enology, The Pennsylvania State University, 318 Tyson Building, University Park, PA 16802

Funding for this work was received by the U.S. Department of Agriculture, the North Carolina Grape and Wine Council, and the Southern Region Small Fruits Consortium.

We thank Emma Volk (North Carolina State University), Amy Lynn-Alberts, Michael Finn, and Abby Whitacker (all of the North Carolina Cooperative Extension) for sample acquisition in 2018 and 2019. We further thank Dr. Penelope Perkins-Veazie (North Carolina State University) for editing this manuscript before submission, and Emma Volk (North Carolina State University) for editing after reviews.

M.H. is the corresponding author. E-mail: mark. hoffmann@ncsu.edu.

This is an open access article distributed under the CC BY-NC-ND license (https://creativecommons. org/licenses/by-nc-nd/4.0/).

https://doi.org/10.21273/HORTTECH04765-20 commercial wine and fresh-market production since the early $1800 \mathrm{~s}$ (Hickey et al., 2019; Hoffmann et al., 2020; Olien, 1990a, 1990b). Muscadines are morphologically and genetically distinct from most other grape (Vitis) species, showing thinner bark, denser wood, a continuous pith, unbranched tendrils, small fruit clusters, thicker fruit skins and soft pulp, a unique fruit aroma, the presence of an abscission zones between fruit and the rachis, and a set of 40 chromosomes (while other grape species only have 38) (Conner, 2009; Hickey et al., 2019; Hoffmann et al., 2020; Milholland, 1991; Olien, 1990a, 1990b). In commercial production systems, vines are planted as dormant bare-root plants in the spring, usually with $20 \mathrm{ft}$ between-vine spacing and a row width of usually 10-12 ft. Vines are trained as bilateral cordon on a single high wire (Fig. 1A), with a less confined fruit-zone compared with bunch grape (Vitis vinifera) production (Hoffmann et al., 2020). Most fruit ripens between the end of August and mid-October, although fruit ripening is not even. 'Carlos' and 'Noble' are the most widely planted muscadine cultivars in the industry and are predominantly used for processing. 'Carlos' has small-to-medium-sized bronze-color fruit (Fig. 1C), while 'Noble' has similar-sized dark-colored fruit (Fig. 1D). Muscadines are well adapted to the humid and subtropical climate in the southern United States, and they are resistant or tolerant to grape diseases such as Pierce's disease (Xylella fastidiosa), downy mildew (Plasmopara viticola), or phomopsis (Phomopsis viticola) (Clark and Spiers, 2001; Milholland, 1991; Olien, 1990a, 1990b; Stringer et al., 2008).

Bud break is a key indicator to start fertilizer applications, recurring on a 4- to 6-week basis until $\mathrm{N}$ requirements are met. However, the timing of tissue sampling for fertility management in muscadines is rather loosely defined, based on calendar dates, but not on vine growth stage (Hoffmann et al., 2020). This stands in contrast to nutrition management practices established in juice and wine bunch grape vineyards that rely on temporally based tissue sampling to compared with standardized sufficiency ranges (Benito et al., 2013; Christensen, 1969; Fallahi et al., 2005a, 2005b; García-Escudero et al., 2013; Goldammer, 2018; Köse et al., 2018; Romero et al., 2013; Schreiner and Scagel, 2017; Wolf, 2008). While a few studies address the dynamics of muscadine tissue nutrient status in relation to sampling time, questions remain as to whether similar patterns are observed at different vineyard locations and across different cultivars

\begin{tabular}{llll}
\hline $\begin{array}{l}\text { Units } \\
\text { To convert U.S. to SI, } \\
\text { multiply by }\end{array}$ & U.S. unit & SI unit & $\begin{array}{l}\text { To convert SI to U.S., } \\
\text { multiply by }\end{array}$ \\
\hline 0.3048 & $\mathrm{ft}$ & $\mathrm{m}$ & 3.2808 \\
2.54 & inch $(\mathrm{es})$ & $\mathrm{cm}$ & 0.3937 \\
1.1209 & $\mathrm{lb} / \mathrm{acre}$ & $\mathrm{kg} \cdot \mathrm{ha}^{-1}$ & 0.8922 \\
1 & $\mathrm{meq} / 100 \mathrm{~g}$ & $\mathrm{cmol} \cdot \mathrm{kg}^{-1}$ & 1 \\
1 & $\mathrm{ppm}$ & $\mathrm{mg} \cdot \mathrm{kg}^{-1}$ & 1 \\
$\left({ }^{\circ} \mathrm{F}-32\right) \div 1.8$ & ${ }^{\circ} \mathrm{F}$ & ${ }^{\circ} \mathrm{C}$ & $\left({ }^{\circ} \mathrm{C} \times 1.8\right)+32$
\end{tabular}



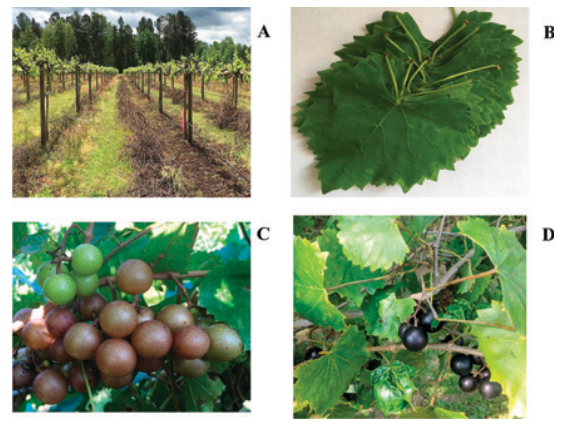

Fig. 1. A commercial muscadine vineyard at budbreak (A). Whole leaf tissue samples (B). Fruit clusters of muscadine cultivars Carlos (C) and Noble (D). Muscadines are mostly planted at $10 \times 20$-ft row-to-row and plant-to-plant spacing with single high-wire trellis system $(6 \mathrm{ft}$ above the ground); $1 \mathrm{ft}=0.3048 \mathrm{~m}$.

(Boswell et al., 1980; Cummings, 1977; Spiers and Braswell, 1993, 1994). Thus recommendations for sampling specific tissues at specific growth stages lack scientific support. As such, it is common practice in muscadine vineyards to test muscadine leaf tissue once, using the whole leaf (blade + petiole) in June/early July (Clark and Spiers, 2001; Hoffmann et al., 2020).

The sufficiency/deficiency range for macro and micronutrients in muscadine tissue samples is based on mostly anecdotal knowledge (Bryson et al., 2014; K.A. Hicks, personal communication), and specific information based on grapevine growth stage and/or muscadine cultivar are not very well established in 2021 (Bryson et al., 2014). Most of the muscadine production guides, for instance, do not provide tissue nutrient sufficiency ranges (Andersen et al., 2018; Cline, 2020; Krewer and Myers, 2009; Stafne, 2016). The sufficiency ranges that are reported are based on the general recommendations for whole-leaf nutrient concentration (Jones and Mills, 1996), which recommend leaf sampling for tissue analysis in mid- or late summer (Hoffmann et al., 2020). Because of those limitations, muscadine growers are left with unrefined tissue sampling methods and a generic guideline for nutrient sufficiency ranges (Hoffmann et al., 2020; Olien, 1990a, 1990b), which stands in contrast to the detailed tissue nutrient guidelines provided for nutrient management in bunch grape (e.g., Avery et al., 2003; Davenport and Horneck,
2011; Moyer et al., 2018; Shellie and Brown, 2012; Wolf, 2008). The objective of the presented study was to survey the variation of muscadine tissue nutrient concentration between 'Carlos' and 'Noble' at various growth stages and at three different locations. The goal is for this evaluation to serve as a baseline for future work on the development of tissue sampling methods for muscadine grape based on growth stage.

\section{Materials and methods}

Locations. In 2018 and 2019, leaf tissue was collected from commercially grown 'Carlos' and 'Noble' vineyards in south Georgia, north Georgia, and the Piedmont in North Carolina. Sample collection took place at three farms: 1) Piedmont North Carolina (Salisbury, NC; lat. $35^{\circ} 39^{\prime} 48.28^{\prime \prime} \mathrm{N}$, long. $80^{\circ} 34^{\prime} 3.01^{\prime \prime}$ $\mathrm{W}$; elevation $799 \mathrm{ft}$ ). No fertilizer was applied at the North Carolina site during the 2 years of investigation. 2) North Georgia (Braselton, GA; lat. $34^{\circ} 05^{\prime} 55.98^{\prime \prime} \mathrm{N}$, long. $83^{\circ} 49^{\prime} 04.50^{\prime \prime}$ $\mathrm{W}$; elevation $927 \mathrm{ft}$ ). A total of $80 \mathrm{lb} /$ acre of $14 \mathrm{~N}-0.86 \mathrm{P}-6.64 \mathrm{~K}$ in split applications $(30 \mathrm{lb} /$ acre at budbreak and $50 \mathrm{lb} /$ acre at bloom) was applied at north Georgia in both years. 3) South Georgia (Arlington, GA; lat. $31^{\circ} 26^{\prime} 21.09^{\prime \prime} \mathrm{N}$, long. $84^{\circ} 37^{\prime} 20.88^{\prime \prime}$ $\mathrm{W}$; elevation $213 \mathrm{ft}$ ). A total of 600 $\mathrm{lb} /$ acre of $10 \mathrm{~N}-4.4 \mathrm{P}-8.3 \mathrm{~K}$ fertilizer was applied at bud-break in both years. All vineyards were mature. The Piedmont North Carolina site has Lloyd clay loam soils (Rhodic Kanhapludults). The soil at the north Georgia site is Cecil sandy clay loam (Typic Kanhapludults). The south Georgia site soil is Greenville sandy loam (Rhodic Kandiudults). No irrigation systems were used at any of the field locations.

LEAF TISSUE ASSESSMENT. Whole leaf samples were collected in nine blocks for each cultivar in each vineyard (total of 18 blocks per vineyard). Each block consisted of four to six muscadine vines in the same row. Each block was sampled at bloom, véraison, and postharvest in 2018 and 2019. At bloom, samples were collected from primary shoots opposite clusters; at véraison and postharvest, samples were collected from the first fully expanded leaf of a primary shoot. From each block, 60 leaves (Clark and
Spiers, 2001; Hoffmann et al., 2020) were randomly collected and combined into one composite sample. In 2018, leaf tissue samples at bloom were collected on 29 May, 7 June, and 19 June 2018 from the commercial vineyards of south Georgia, north Georgia, and Piedmont North Carolina, respectively. The samples at véraison were collected on 7,15 , and 30 Aug. 2018; and at postharvest, samples were collected on 1,5 , and 26 Oct. 2018 from south Georgia, north Georgia, and Piedmont North Carolina, respectively. In 2019, samples at bloom were collected on 17 June 2019 from south Georgia and Piedmont North Carolina, and on 21 June 2019 from north Georgia. Véraison samples were collected on 31 July, 21 Aug., and 3 Sept. 2019, and postharvest samples were collected on 2 Oct., 30 Oct., and 4 Nov. 2019 from south Georgia, north Georgia, and Piedmont North Carolina, respectively.

Leaf tissue samples were dried to a constant weight at 60 to $80^{\circ} \mathrm{C}(31$ 350 Analog Bench Oven; Quincy Laboratory, Chicago, IL) before sending the samples to an analytical laboratory. The samples were analyzed for nitrogen $(\mathrm{N})$, phosphorous $(\mathrm{P})$, potassium $(\mathrm{K})$, magnesium $(\mathrm{Mg})$, calcium $(\mathrm{Ca})$, sulfur $(\mathrm{S})$, boron $(\mathrm{B})$, zinc $(\mathrm{Zn})$, manganese $(\mathrm{Mn})$, iron (Fe), and copper ( $\mathrm{Cu})$ by Waters Agricultural Laboratories (Camilla, GA). Dried leaves were ground to pass through a 20 -mesh screen. The samples were reduced to ash in a muffle furnace, acid digested (Nelson and Sommers, 1973), and measured by inductive coupled plasma spectrophotometer (ICP) coupled to a highcapacity digestion system (Digiblock 3000; SCP Science, Baie D’Urfé, QC, Canada). $\mathrm{N}$ was determined through dry combustion of plant tissue using an $\mathrm{N}$ analyzer (FP-428; LECO, St. Joseph, MI).

SoIL TESTING. A composite soil sample was taken from the vineyard floor under the canopy in Spring 2018. Each sample was taken at 0 to 6 inches depth with the surface 1 inch removed. In all three vineyards, major amounts of feeder roots were found in the top 6 inches. Combined soil samples were analyzed for nutrient concentration $(\mathrm{P}, \mathrm{K}, \mathrm{Mg}$, and $\mathrm{Ca}$ ) as well as for $\mathrm{pH}$, cation exchange 
capacity (CEC), and organic matter content (OM) by Waters Agricultural Laboratories, using the Mehlich I procedure. The $\mathrm{pH}$ was measured using a 0.01 molar calcium chloride solution in a $1: 1$ soil-to- $\mathrm{CaCl}_{2}$ mixture and reported as an adjusted $\mathrm{pH}$ value of +0.6 units.

Statistics. The leaf tissue nutrient data were analyzed using SAS (version 9.4 for Windows; SAS Institute, Cary, NC). Replications were nine blocks for each cultivar in each location, from which a total of 60 leaf samples were taken per replicate. The replications and cultivars were used in the RANDOM and LSMEANS statement on PROC GLIMMIX, respectively, resulting in 1 numerator degree of freedom (df) and 8 denominator df. Thus, mean nutrient values of two cultivars were compared for each location. The mean values were separated at $P<0.05$ level using Tukey adjustment. The soil data were analyzed using PROC GLM in SAS to compare the soil properties in three different locations. Means were separated at the $P<0.05$ level using Fisher's least significant difference test.

\section{Results}

Comparison OF LEAF TISSUE NUTRIENT CONCENTRATION TO THE RECOMMENDED SUFFICIENCY RANGE. The concentration of several nutrients in leaf tissue was consistently outside of the recommended sufficiency range across all locations, cultivars, and growth stages (Tables 1 and 2). Most prominently, leaf tissue $\mathrm{N}$ concentration was within or above the recommended sufficiency range in both cultivars over most sampling dates. Leaf tissue $P$ was above the sufficiency range at bloom and véraison at the Piedmont North Carolina vineyard, but it was within the range during all sampling dates at the other two vineyard locations. Leaf tissue $\mathrm{Mg}$ was above the sufficiency range in the Piedmont North Carolina vineyard, but it was within or below the recommended range at the south Georgia and north Georgia vineyards. Leaf tissue $\mathrm{K}$ in all three locations was within or above the range at bloom but below the sufficiency range at the end of the season. Moreover, leaf tissue Ca and $\mathrm{Mn}$ was above the sufficiency ranges at all sampling dates, at all locations, and across both cultivars. Leaf tissue $\mathrm{Zn}$ and $\mathrm{S}$ was below the sufficiency range at the Piedmont North Carolina and south Georgia location, respectively.

DifFERENCES IN LEAF-TISSUE NUTRIENT CONCENTRATION BETWEEN CULTIVARs. There were three overarching trends when comparing leaf tissue nutrient concentration between 'Carlos' and 'Noble' over the years 2018 and 2019 in three locations (Tables 3-5). First, across all vineyard sites and sampling years, 'Carlos' had greater leaf tissue $\mathrm{N}$ when compared with 'Noble'. Second, across two vineyard sites and both sampling years, leaf tissue $\mathrm{P}$ was higher in 'Carlos' when it was compared with 'Noble'. Third, across all vineyard sites and sampling years, leaf tissue Mn was higher in 'Noble' when compared with 'Carlos'. What follows are noteworthy site-specific observations in tissue differences among cultivars.

Piedmont North Carolina. 'Carlos' had greater leaf tissue $\mathrm{N}$ and $S$ during véraison and after harvest in 2018 , and at bloom and véraison in 2019 (Table 3). Leaf tissue P was greater in 'Carlos' when compared with 'Noble' at bloom in 2019 and after harvest in both years. Finally, excepting at bloom in 2018, 'Noble' generally had greater leaf tissue $\mathrm{Mn}$ than 'Carlos'.

North Georgia. 'Carlos' had greater leaf tissue $\mathrm{N}$ than 'Noble' at véraison and after harvest in 2018 (Table 4). Leaf tissue $\mathrm{P}$ was also higher in 'Carlos' compared with 'Noble' at véraison and after harvest in 2018, and at bloom in 2019. 'Carlos' had greater leaf tissue Ca than 'Noble' at véraison and after harvest in both years. 'Noble' had greater leaf tissue K than 'Carlos' in both years. The tissue concentration of several micronutrients ( $\mathrm{B}, \mathrm{Zn}$, and $\mathrm{Mn}$ ) was higher in 'Noble' than in 'Carlos' in both years.

South Georgia. 'Carlos' had greater leaf tissue $\mathrm{N}$ than 'Noble' at véraison and after harvest in 2018, and across all sampling dates in 2019 (Table 5 ). 'Noble' had greater leaf tissue Mn compared with 'Carlos', except at bloom in 2019.

SOIL NUTRIENT STATUS AND PROPERTIES. Soil nutrient concentration at the Piedmont North Carolina vineyard showed lower $\mathrm{P}$ and higher $\mathrm{Ca}$ and $\mathrm{Mg}$ (Table 6). The soil at the Piedmont North Carolina location also had greater OM (4.6\%) and CEC when compared with the other two vineyard locations. The north Georgia and south Georgia locations had greater $\mathrm{P}$, but lower $\mathrm{pH}$ and $\mathrm{Ca}$, than the North Carolina vineyard.

\section{Discussion}

Comparison OF LEAF TISSUE NUTRIENT CONCENTRATION WITH THE RECOMMENDED SUFFICIENCY RANGE. Our results show that current leaf tissue nutrient concentration recommendations do not apply to all nutrient elements, locations, cultivars, and vine growth stages. Rather, muscadine leaf tissue nutrient concentration is highly dependent on cultivar, growth stage and region. Carlos and Noble are both considered highly vigorous cultivars (Hickey et al., 2019; Hoffmann et al., 2020; Olien, 1990a). Leaf-tissue N, Ca, and Mn concentrations were above the sufficiency range in both cultivars throughout the sampling times and locations. However, excess $\mathrm{N}$ can have antagonistic effects on other elements in the vine such as $\mathrm{K}$ and $\mathrm{Ca}$ (Goldammer, 2018). In our study, K concentration was below sufficiency range at véraison and after harvest in all three regions. While the relatively high soil OM at the Piedmont North Carolina location could serve as an $\mathrm{N}$ source, north Georgia and south Georgia used medium-to-high rates of $\mathrm{N}$ fertilizer. Applying $\mathrm{N}$ fertilizer where its concentration is already above the sufficiency range could be counterintuitive from a few perspectives. First, excess $\mathrm{N}$ would increase the plant vigor (Arrobas et al., 2014; Benito et al., 2013; García-Escudero et al., 2013), which may increase disease incidence and delay fruit ripening because of reduced sunlight interception and higher humidity in the canopy, respectively (Schreiner et al., 2014). Second, excess $\mathrm{N}$ could lead to K deficiency (Arrobas et al., 2014), which could indirectly reduce the juice/wine quality by reducing sugar and color compounds (García-Escudero et al., 2013), or result in excessive yeast assimilable N (YAN) in fruit, negatively affecting wine quality (Schreiner et al., 2014). Finally, an increase in canopy vigor may increase time and labor spent on dormant pruning, which is one of the major labor efforts in muscadine production systems (Hoffmann et al., 2020). 


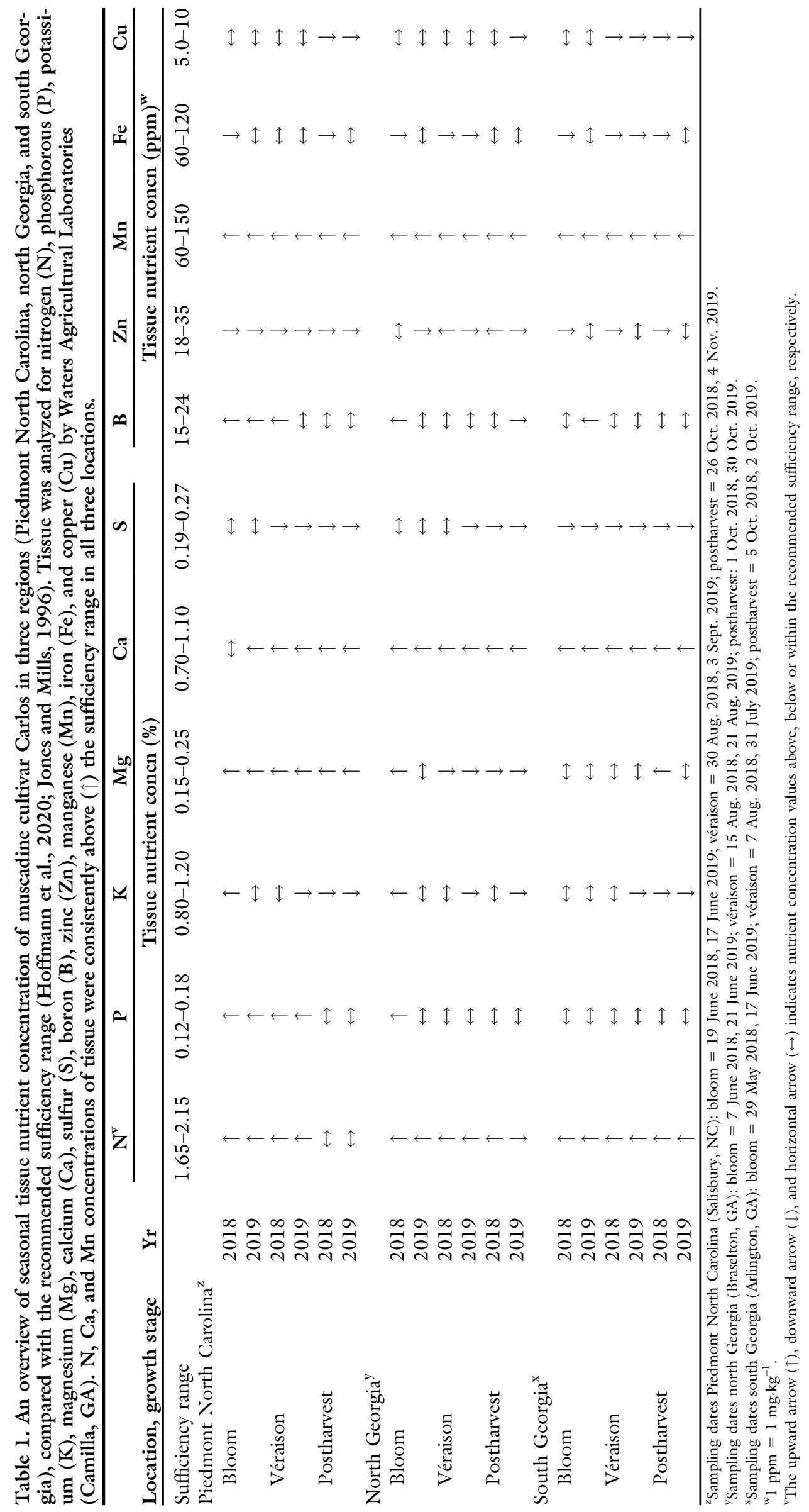

Hortlechnology • June 2021 31(3) 


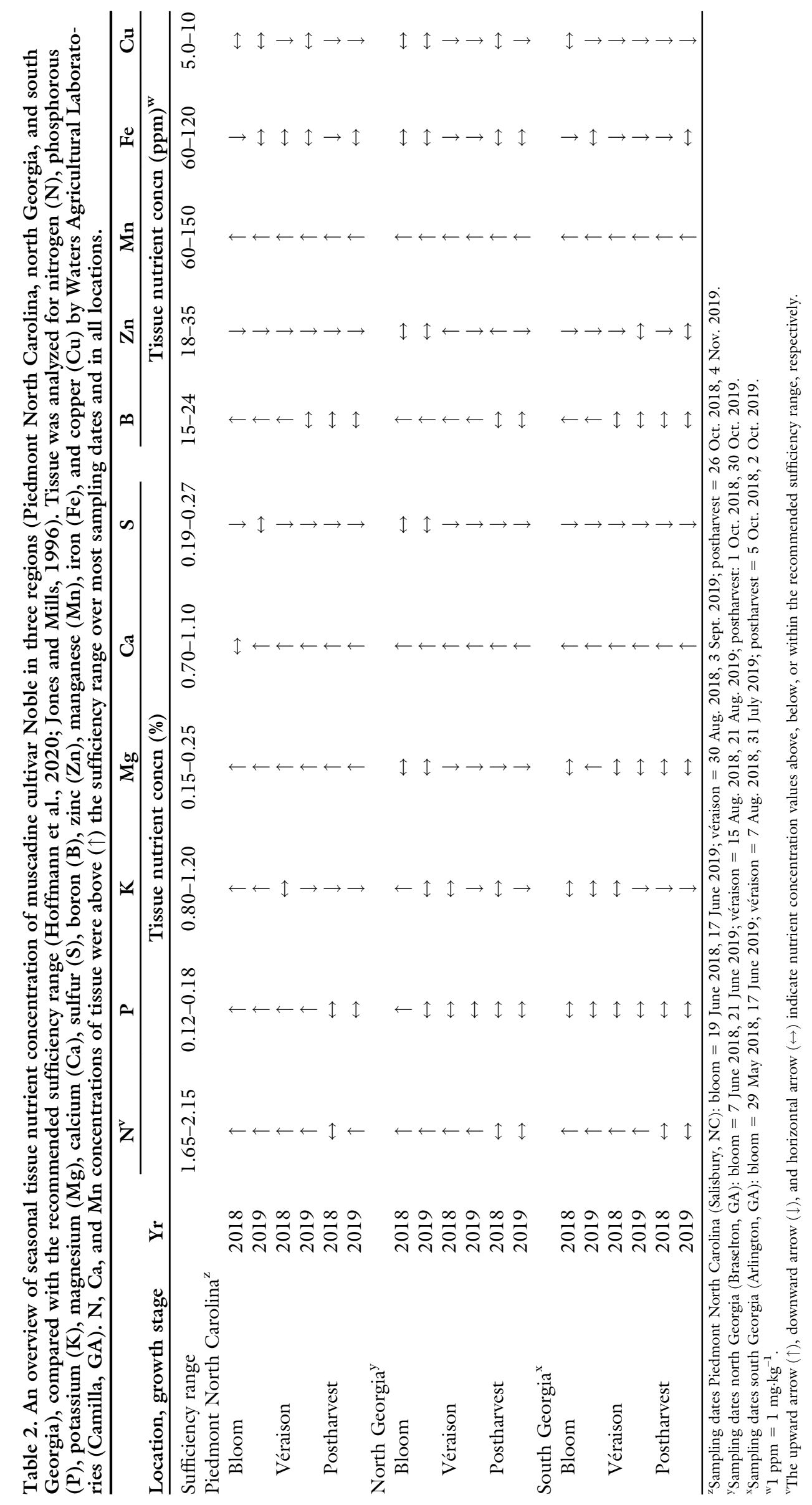




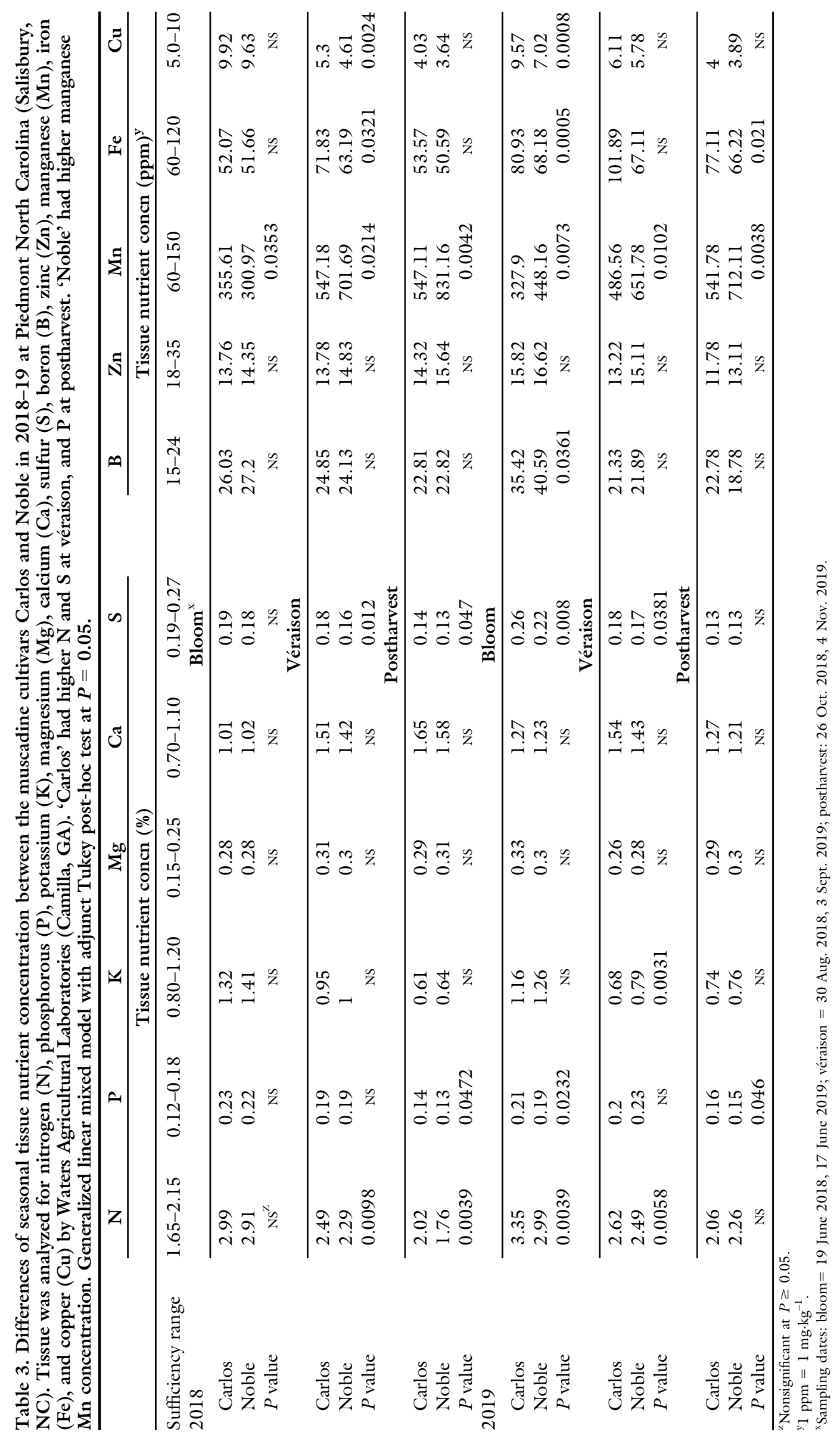




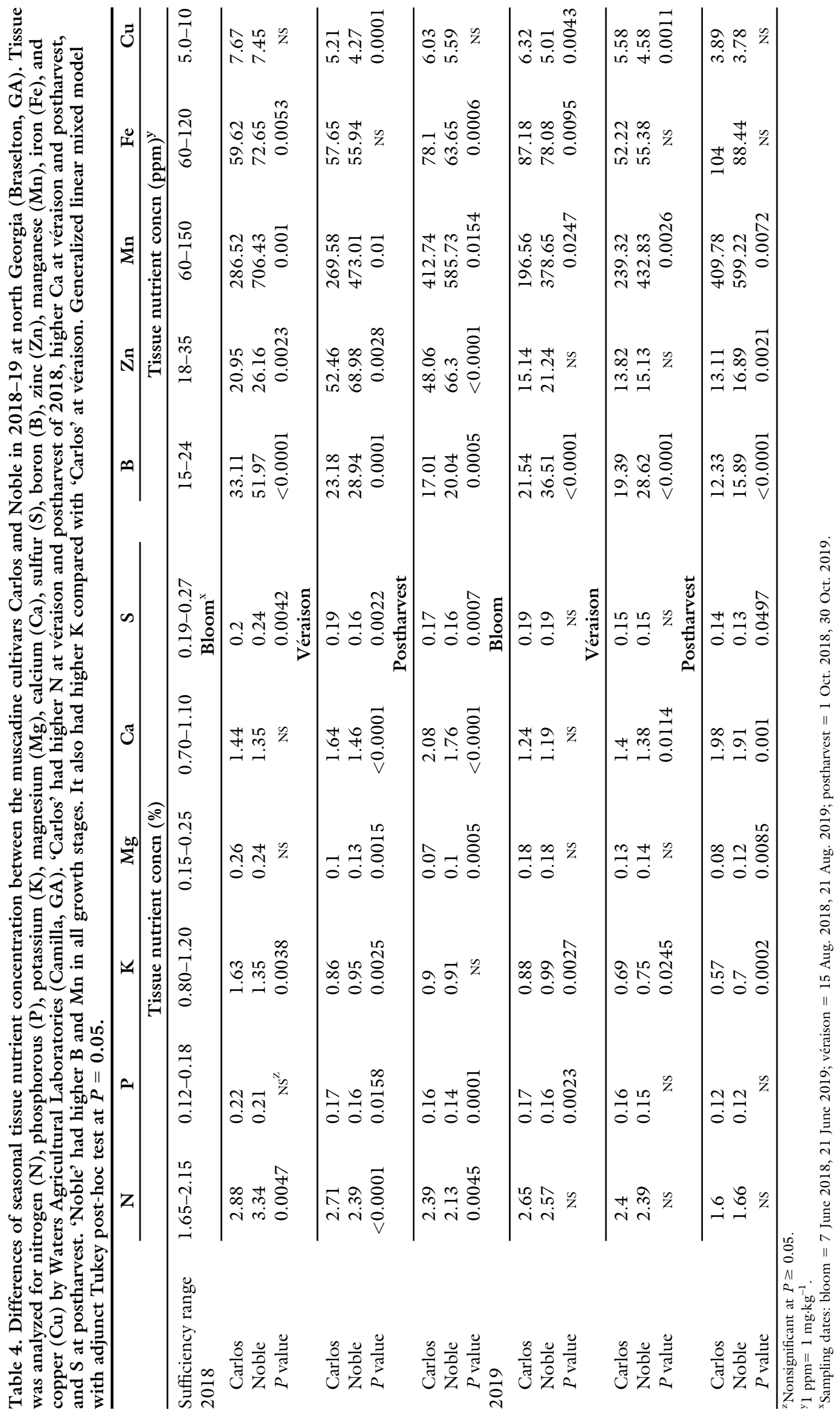




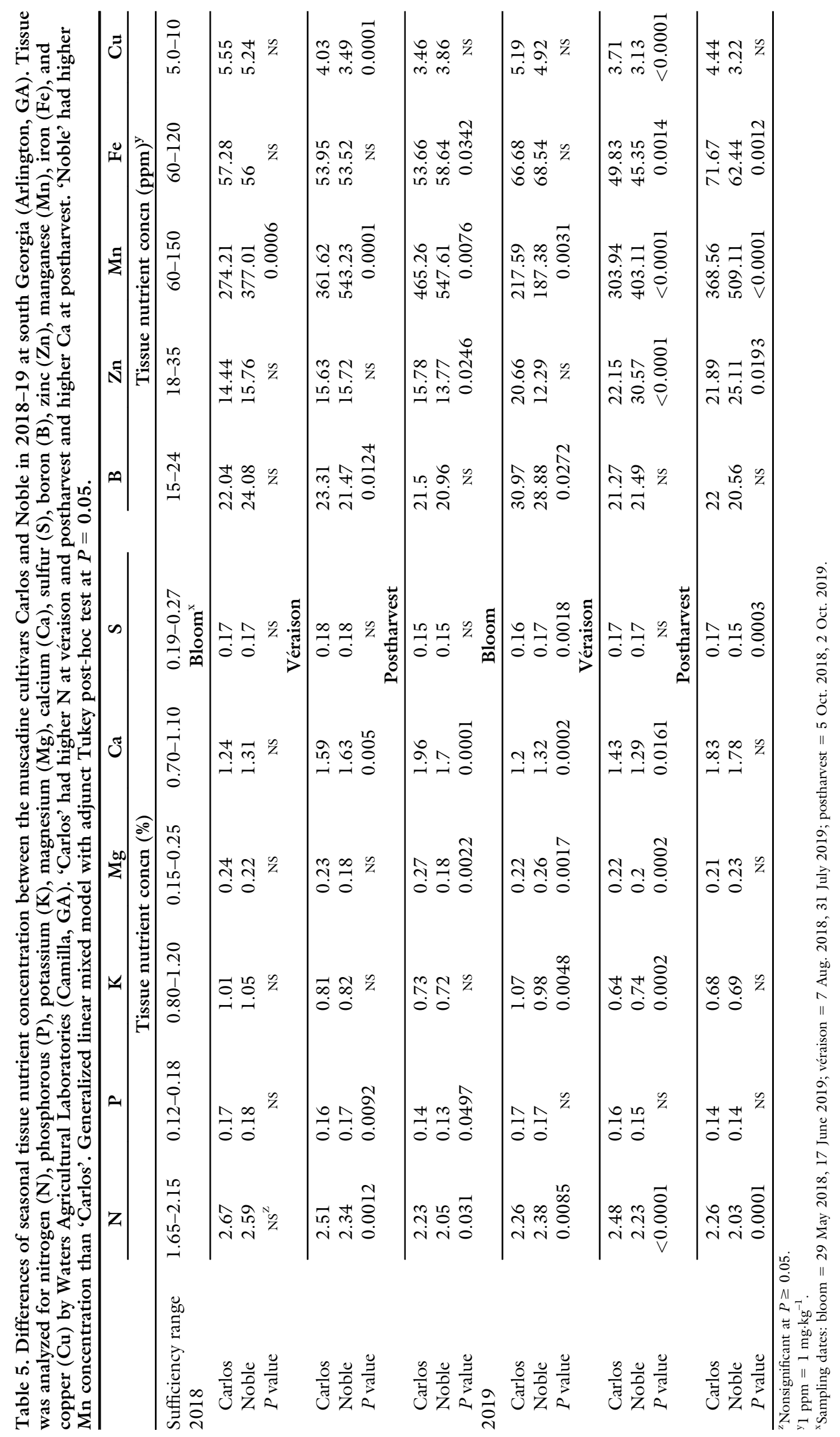


Table 6. Soil nutrient concentration at three muscadine vineyard locations [Piedmont North Carolina (Salisbury, NC), north Georgia (Braselton, GA), and south Georgia (Arlington, GA)] at the beginning of the study (sample date: Mar. 2018). Soil samples were analyzed for phosphorous $(\mathrm{P})$, potassium $(\mathrm{K})$, magnesium $(\mathrm{Mg})$, calcium $(\mathrm{Ca})$, pH, cation exchange capacity (CEC), and organic matter (OM) by Waters Agricultural Laboratories (Camilla, GA). Soil samples were taken in Mar. 2018 in each location before the fertilizer application. ANOVA with Fisher's least significant difference at $P=0.05$.

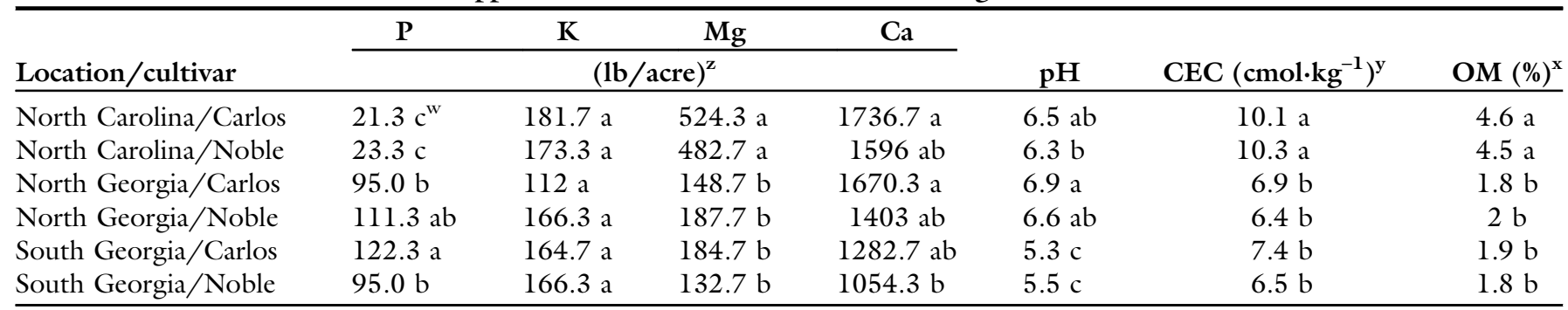

${ }^{\mathrm{z}} \mathrm{lb} / \mathrm{acre}=1.1209 \mathrm{~kg} \cdot \mathrm{ha}^{-1}$.

${ }^{\mathrm{y}}$ Cation exchange capacity; $1 \mathrm{cmol} \cdot \mathrm{kg}^{-1}=1 \mathrm{meq} / 100 \mathrm{~g}$.

${ }^{\mathrm{x}}$ Soil organic matter.

${ }^{w}$ Means followed by a different letter within a column and within a cultivar are significantly different at $P=0.05$ according to Fisher's least significant difference.

Leaf tissue $\mathrm{P}$ and $\mathrm{Mg}$ was above the recommended sufficiency ranges in both cultivars at the Piedmont North Carolina vineyard (Tables 1 and 2). The ideal $\mathrm{pH}$ range is $6-7$, a range at which nutrients are generally available for plant uptake. For example, $\mathrm{Ca}, \mathrm{Mg}$, and $\mathrm{P}$ are less available for plant uptake at acidic $\mathrm{pH}$ values, while $\mathrm{Fe}$ and $\mathrm{Mn}$ are less available for plant uptake at alkaline $\mathrm{pH}$ values (Goldammer, 2018). Differences in soil $\mathrm{pH}$ and $\mathrm{Mg}$ concentration in soil between the Piedmont North Carolina and the Georgia locations could have led to higher $\mathrm{Mg}$ plant availability in the Piedmont location. Cummings and Lilly (1984) reported increased soil and foliar $\mathrm{Mg}$ concentration due to a shift from a soil $\mathrm{pH}$ of 5 to a soil $\mathrm{pH}$ of 7 . Greater soil CEC means that greater amounts of positively charged/cationic nutrients (e.g., $\mathrm{Ca}, \mathrm{Mg}, \mathrm{K}$, etc.) bind to the soil, which otherwise would be lost via leaching; greater CEC buffers soil $\mathrm{pH}$ and prevents an abrupt decrease in soil $\mathrm{pH}$. Moreover, higher soil OM content also buffers soil $\mathrm{pH}$ because its negatively charged surfaces have greater affinity for cations and other organic molecules (Goldammer, 2018). Thus, the higher soil OM content and CEC at the Piedmont North Carolina location may have l) contributed to the "optimal" soil $\mathrm{pH}$ condition compared with other two places in Georgia (especially compared with south Georgia); and 2) increased relative nutrient availability for plant uptake, even under the minimal fertilizer regime. In the humid, subtropical growing regions of Georgia and North Carolina, where heavy rainfall events and tropical storms have the potential to result in the excessive leaching of cations and reducing of soil pH (e.g., create acidic soils), possibly greater soil OM and CEC may help maintain muscadine nutrient balance without exogenous fertilizer application.

Leaf tissue nutrient sufficiency ranges, as published in current muscadine production guides (e.g., Hoffmann et al., 2020), do not accurately reflect nutrient dynamics in muscadine production. Leaf tissue $\mathrm{N}, \mathrm{Ca}$, and $\mathrm{Mn}$ concentrations were consistently above the recommended sufficiency range in all three vineyard locations. Standards for nutrient sufficiency ranges for bunch grape cultivars are continuously studied and updated (García-Escudero et al., 2013; Goldammer, 2018; Wolf, 2008). Ranges for tissue macronutrients for bunch grape cultivars are also outside the recommended sufficiency ranges for muscadines by Jones and Mills (1996). Generally, studies on bunch grape cultivars suggest that tissue nutrient concentration varies according to several factors, including growth stage, fertilization, the tissue type that is sampled (Benito et al., 2013; Köse et al., 2018; Romero et al., 2013; Schreiner and Scagel, 2017), irrigation practice (Davenport et al., 2012; Shellie and Brown, 2012), and rootstock and cultivar combinations (Fallahi et al., 2005a, 2005b; García-Escudero et al., 2013). In bunch grape cultivars, leaf blade sampling is recommended to identify $\mathrm{N}, \mathrm{P}, \mathrm{K}, \mathrm{Mn}$, and $\mathrm{Zn}$ status (Benito et al., 2013; Romero et al., 2013; Schreiner and Scagel, 2017), while petioles better represent the Fe and $\mathrm{B}$ status of the vine (Romero et al., 2013; Schreiner and Scagel, 2017). This study is not designed to develop a set of leaf tissue nutrient recommendations, yet it serves as a survey to understand the general trend in wholeleaf tissue nutrient concentration across growing regions for muscadines. However, based on our preliminary results, the muscadine leaf tissue nutrient sufficiency ranges for $\mathrm{N}, \mathrm{Ca}$, and Mn may need to be reevaluated and adjusted accordingly.

DifFERENCES IN LEAF-TISSUE NUTRIENT CONCENTRATION BETWEEN THE MUSCADINE CULTIVARs. Leaf tissue samples from 'Carlos' showed significantly higher $\mathrm{N}$ and $\mathrm{P}$ than 'Noble' in all locations and during most sampling dates. However, leaf tissue samples from 'Noble' had significantly higher Mn concentration through all locations and most sampling dates. To our knowledge, this is the first time that the differences in leaf tissue nutrient concentration was reported between muscadine cultivars. However, the differences in tissue nutrient concentration have been shown to vary across bunch grape cultivars (Fallahi et al., 2005a, 2005b), with possible causes speculated to be differences in root structure, growth differences, and/or size, and/or number of the leaves per vine (Fallahi et al., 2005a, 2005b). 'Noble' anecdotally has less vigorous growth and smaller berry size than 'Carlos' (Conner, 2009). Fallahi et al. (2005a) also reported a positive correlation of leaf $\mathrm{N}$ with 
cluster size in a wide range of ownrooted bunch grape cultivars.

Leaf tissue N, P, and $\mathrm{K}$ decreased over the season in both cultivars ( $\mathrm{Ta}-$ bles 3-5). Leaf tissue $\mathrm{Ca}$ and $\mathrm{Mn}$, however, increased as the season progressed, while $\mathrm{Mg}$ did not show any distinct seasonal fluctuation. These patterns were similar with work on other fruit crops and in grapes (e.g., Cummings et al., 1973, Benito et al., 2013, and Romero et al., 2013). Mobilization of $\mathrm{N}$ and $\mathrm{P}$ to sinks such as leaves, fruit, and meristems is responsible for the seasonal decrease in concentrations of these nutrients (Benito et al., 2013). However, Ca is less mobile in leaf tissue and may accumulate in leaves as they mature (Benito et al., 2013). Our observed patterns of seasonal leaf-tissue nutrient concentration dynamics were similarly observed before in the muscadine cultivar Sterling (Spiers and Braswell, 1993). Fallahi et al. (2005a, 2005b) also reported the negative correlation between leaf tissue concentration of $\mathrm{N}$, $\mathrm{Mg}$, and $\mathrm{Ca}$, and a positive correlation between $\mathrm{N}$ and $\mathrm{K}$ in a wide range of bunch grape cultivars. Thus, the observed patterns of change in leaf nutrient concentrations with different seasonal stages in this study were like other grape types or cultivars.

\section{Conclusions}

The results of this study strongly suggest that $\mathrm{N}, \mathrm{P}, \mathrm{K}, \mathrm{Ca}$, and $\mathrm{Mn}$ tissue sufficiency ranges for muscadines need to be reevaluated. We further show that nutrient dynamics in muscadine leaf tissue is highly influenced by cultivar and seasonal stage, while location only had a marginal impact on leaf tissue nutrient concentration. We demonstrate the need to adjust the recommended leaf tissue sufficiency ranges for muscadines as well as the need for further research to develop a comprehensive muscadine nutrient management system that accounts for cultivar, growth stage, and the specific tissue being sampled.

\section{Literature cited}

Andersen, P.C., T.E. Crocker, and J. Breman. 2018. The muscadine grape. Univ. Florida, Inst. Food Agr. Sci. Ext. HS763. 29 Jan. 2021. <https://edis.ifas. ufl.edu/hs100>.
Arrobas, M., I.Q. Ferreira, S. Freitas, J. Verdial, and M.A. Rodrigues. 2014. Guidelines for fertilizer use in vineyards based on nutrient concentration of grapevine parts. Scientia Hort. 172:191-198, doi: 10.1016/j.scienta.2014.04.016 0304-4238.

Avery, J.D., P.L. Byers, S.F. Howard, M.L. Kaps, L.G. Kovacs, J.F. More Jr, M.B. Odneal, W. Qiu, J.L. Saenz, S.R. Teghtmeyer, H.G. Townsend, and D.E. Waldstein. 2003. Growing grapes in Missouri. State Fruit Expt. Sta. MS-29. 29 Jan. 2021. <https://ag.missouristate.edu/ Assets/MtnGrv/MS29grapeguide.pdf > .

Benito, A., I. Romero, N. Domínguez, E. García-Escudero, and I. Martin. 2013. Leaf blade and petiole analysis for nutrient diagnosis in Vitis vinifera L. cv. Garnacha tinta. Aust. J. Grape Wine Res. 19:285-298, doi: 10.1111/ajgw.12022.

Boswell, F.C., R.P. Lane, and K. Ohki. 1980. Field studies with boron on muscadine grapes. Commun. Soil Sci. Plant Anal. 11:201-207, doi: 10.1080/001036 28009367028.

Bryson, G.M., H.A. Mills, D.N. Sasseville, J.B. Jones, Jr., and A.V. Barker (eds.). 2014. Plant analysis handbook III. MicroMacro Publ., Athens, GA.

Christensen, P. 1969. Seasonal changes and distribution of nutritional elements in Thompson seedless grapevines. Amer. J. Enol. Viticult. 20:176-190.

Clark, J.R. and J.M. Spiers. 2001. Irrigation and mineral nutrition, p. 169-187. In: F.M. Basiouny and D.G. Himelrick (eds.). Muscadine grape. ASHS Press, Alexandria, VA.

Cline, B. (ed.). 2020. 2020 Southeast regional muscadine grape integrated management guide. 29 Jan. 2021. <https:// smallfruits.org/files/2019/06/MuscadineIMG.pdf $>$.

Conner, P.J. 2009. Performance of muscadine grape cultivars in south Georgia. J. Amer. Pomol. Soc. 63:101-107.

Cummings, G.A. 1977. Variation in the concentration of certain elements in muscadine grape leaves related to season leaf portion, and age. J. Amer. Soc. Hort. Sci. 103:339-342.

Cummings, G.A., A.S. Fish, W.B. Nesbitt, and V.H. Underwood. 1973. The influence of mineral nutrition and time of year upon the elemental concentration of muscadine grapes (Vitis rotundifolia). Commun. Soil Sci. Plant Anal. 4:211-218.

Cummings, G.A. and P. Lilly. 1984. Soil $\mathrm{pH}$ rate for fruit yield and elemental composition of muscadine grapes. HortScience 19:831-832.
Davenport, J.R. and D.A. Horneck. 2011. Sampling guide for nutrient assessment of irrigated vineyard in the inland Pacific Northwest. Pacific Northwest Ext. Publ. PNW622. 29 Jan. 2021. < http://css. wsu.edu/irrsoils/files/2013/03/PNW622Davenport-Horneck-2011.pdf $>$.

Davenport, J.R., J.D. Lunden, and T. Winkler. 2012. Wine grape tissue nutrient concentration in the inland Pacific Northwest. Commun. Soil Sci. Plant Anal. 43:21-27, doi: 10.1080/00103624.2012.631395.

Fallahi, E., B. Shafii, J.C. Stark, and B. Fallahi. 2005a. Cane and leaf growth and leaf mineral nutrients in various cultivars of wine grapes. J. Amer. Pomol. Soc. 59:182-191.

Fallahi, E., B. Shafii, J.C. Stark, B. Fallahi, and S.L. Hafez. 2005b. Influence of wine grape cultivars on growth and leaf blade and petiole mineral nutrients. HortTechnology 15:825-830, doi: 10.21273/ HORTTECH.15.4.0825.

García-Escudero, E., I. Romero, A. Benito, N. Domínguez, and I. Martin. 2013. Reference levels for leaf nutrient diagnosis of $\mathrm{cv}$. Tempranillo grapevine in the Rioja Appellation. Commun. Soil Sci. Plant Anal. 44:645-654, doi: 10.1080/0010 3624.2013.745385.

Goldammer, T. 2018. Grape grower's handbook: A guide to viticulture for wine production. 3rd ed. Apex Publ., Centreville, VA.

Hickey, C.C., E.D. Smith, S. Cao, and P. Conner. 2019. Muscadine (Vitis rotundifolia Michx., syn. Muscadinia rotundifolia (Michx.) Small): The resilient, native grape of the southeastern U.S. Agriculture 9:131, doi: 10.3390/agriculture9060131.

Hoffmann, M., P. Conner, P. Brannen, H. Burrack, W. Mitchem, B. Cline, P. Perkins-Veazie, and B. Poling. 2020. Muscadine grape production guide for the Southeast. North Carolina State Ext. AG-94. 29 Jan. 2021. <https://content. ces.ncsu.edu/muscadine-grape-productionguide $>$.

Jones, J.B., Jr. and H.A. Mills. 1996. Plant analysis handbook II: A practical sampling, preparation, analysis, and interpretation guide. 2nd ed. Micro-Macro Publ., Athens, GA.

Krewer, G. and S. Myers. 2009. Home muscadines garden. Univ. Georgia. Coop. Ext. Circ. 949. 29 Jan. 2021. <https:// secure.caes.uga.edu/extension/publications /files/pdf/C\%20949_8.PDF>.

Köse, B., A. Horuz, and G. Akinoğlu. 2018. Leaf nutrient status of 'Trakya ilkeren' grape variety (Vitis vinifera L.) in different phenological stages. Acta Sci. Pol. Hortorum Cultus 17:15-24, doi: 10.24 326/asphc.2018.4.2. 
Milholland, R.D. 1991. Muscadine grapes: Some important diseases and their control. Plant Dis. 75:113-117, doi: 10. 1094/PD-75-0113.

Moyer, M.M., S.D. Singer, J.R. Davenport, and G. Hoheisel. 2018. Vineyard nutrient management in Washington state. Washington State Univ. Bul. EMIl1E. 29 Jan. 2021. < http://pubs.cahnrs.wsu.edu /publications/pubs/emllle/>.

Nelson, D.W. and L.E. Sommers. 1973. Determination of total nitrogen in plant material. Agron. J. 65:109-112, doi: 10.2134/agronj1973.000219620065000 $10033 x$.

Olien, W.C. 1990a. The muscadine grape: Botany, viticulture, history, and current industry. HortScience 25:732-739, doi: 10.21273/HORTSCI.25.7.732.

Olien, W.C. 1990b. Muscadine-A classic Southeastern fruit. HortScience 25:726 and 831, doi: 10.21273/HORTSCI.25.7.726.

Romero, I., E. García-Escudero, and I. Martin. 2013. Leaf blade vs. petiole analysis for nutritional diagnosis of Vitis vinifera L. cv. Tempranillo. Amer. J. Enol. Viticult. 64:50-64, doi: 10.5344/ ajev.2012.11004.

Shellie, K. and B. Brown. 2012. Influence of deficit irrigation on nutrient indices in wine grape (Vitis vinifera L.). Agr. Sci. 3:268-273, doi: 10.4236/ as.2012.32031.

Schreiner, R.P. and C.F. Scagel. 2017. Leaf blade versus petiole nutrient tests as predictors of nitrogen, phosphorus, and potassium status of 'Pinot Noir' grapevines. HortScience 52:174-184, doi: 10. 21273/HORTSCI1 1405-16.

Schreiner, R.P., C.F. Scagel, and J. Lee. 2014. N, P, and K supply to Pinot noir grapevines: Impact on berry phenolics and free amino acids. Amer. J. Enol. Viticult. 65:43-49, doi: 10.5344/ajev.2013.13037.

Spiers, J.M. and J.H. Braswell. 1993. Nitrogen rate and source affects leaf elemental concentration and plant growth in muscadine grapes. J. Plant Nutr. 16: 1547-1554, doi: 10.1080/019041 69309364632

Spiers, J.M. and J.H. Braswell. 1994. Response of 'Sterling' muscadine grape to calcium, magnesium, and nitrogen fertilization. J. Plant Nutr. 17: 1739-1750, doi: 10.1080/01904169 409364843 .

Stafne, E. 2016. Establishment and production of muscadine grapes. Mississippi Coop. Ext. P2290. 29 Jan. 2021. $<$ https://extension.msstate.edu/sites/defa ult/files/publications/publications/p2290_0. pdf $>$.

Stringer, S.J., D.A. Marshall, B.J. Sampson, and J.M. Spiers. 2008. Performance of muscadine grape cultivars in southern Mississippi. HortTechnology 18:726-733, doi: 10.21273/ HORTTECH.18.4.726.

Wolf, T.K. 2008. Wine grape production guide for eastern North America. Plant and Life Science Publ., Ithaca, NY. 